\title{
Reflections Upon Terrorism, Militias, Law, and the Judicial System: An Essay
}

\author{
M.H. Hoeflich*
}

Since 9/11 Americans have focused primarily on the threat of international terrorism. "International terrorism" is defined in the Patriot Act of 2001 ("Patriot Act"), passed immediately after the 9/11 attacks, as activities that:

(A) involve violent acts or acts dangerous to human life that are a violation of the criminal laws of the United States or of any State, or that would be a criminal violation if committed within the jurisdiction of the United States or of any State;

(B) appear to be intended-

(i) to intimidate or coerce a civilian population;

(ii) to influence the policy of a government by intimidation or coercion; or

(iii) to affect the conduct of a government by mass destruction, assassination, or kidnapping; and

(C) occur primarily outside the territorial jurisdiction of the United States, or transcend national boundaries in terms of the means by which they are accomplished, the persons they appear intended to intimidate or coerce, or the locale in which their perpetrators operate or seek asylum; ${ }^{1}$

Much of the Patriot Act, as well as a large number of other statutes, treaties, and other legal instruments provide a legal basis for the investigation and prosecution of those who commit acts of "international terrorism." The federal government was reorganized after $9 / 11$ to better permit our law enforcement, intelligence agencies, and military carry on the fight against global terrorism. ${ }^{2}$ But what of "domestic terrorism"?

\footnotetext{
* John H. \& John M. Kane Distinguished Professor of Law, Director of the M.S. Program in Homeland Security, University of Kansas.

1. 18 U.S.C. $\S 2331(1)$ (2012).

2. See Dana Priest \& William Arkin, A Hidden World, Growing Beyond Control, WASH. PosT
} 
The Patriot Act does, in fact, define "domestic terrorism" in much the same language as it uses to define "international terrorism":

(5) the term "domestic terrorism" means activities that-

(A) involve acts dangerous to human life that are a violation of the criminal laws of the United States or of any State;

(B) appear to be intended-

(i) to intimidate or coerce a civilian population;

(ii) to influence the policy of a government by intimidation or coercion; or

(iii) to affect the conduct of a government by mass destruction, assassination, or kidnapping; and

(C) occur primarily within the territorial jurisdiction of the United States ...

Strangely, however, the Patriot Act provides little authority to prosecute "domestic terrorism," and there are no specific laws that make "domestic terrorism" a crime. Instead, law enforcement must use existing state and criminal laws to prosecute "domestic terrorism" even though domestic terrorism, as I will anecdotally suggest here, poses as much as a threat to the peace and stability of our nation as does "international terrorism." 4

My first encounter, albeit at a distance, with domestic terrorism came soon after I moved to Lawrence, Kansas, to be the dean of the University of Kansas School of Law in June 1994. On April 19, 1995, two Americans, Timothy McVeigh and Terry Nichols, blew up the Alfred P. Murrah Federal Office Building in Oklahoma City, Oklahoma. ${ }^{5}$ One hundred and sixty-eight people are known to have been killed in that

(July 19, 2010), http://projects.washingtonpost.com/top-secret-america/articles/a-hidden-worldgrowing-beyond-control/ [https://perma.cc/GYP4-FGY6] (revealing that as of 2010, thirty-three building complexes had been built in Washington, D.C., and the surrounding area for top-secret intelligence work since $9 / 11 ; 1,271$ government organizations and 1,931 private companies worked on programs related to counterterrorism, homeland security and intelligence; and analysts published 50,000 intelligence reports per year on documents and conversations obtained by foreign and domestic spying).

3. 18 U.S.C. $\S 2331(5)$.

4. See Rafia Zakaria, The Law Needs to Catch Up with the Reality of Domestic Terrorism, CNN (Oct. 29, 2018), https://www.cnn.com/2018/10/29/opinions/domestic-terrorism-legallimitations-rafia-zakaria/index.html [https://perma.cc/C38U-ZQ6L]. See also Mary McCord, It's Time for Congress to Make Domestic Terrorism a Federal Crime, LAWFARE (Dec. 5, 2018), https://www.lawfareblog.com/its-time-congress-make-domestic-terrorism-federal-crime

[https://perma.cc/6R68-LZZ4]. Contra Michael German \& Sara Robinson, Wrong Priorities on Fighting Terrorism, BRENNAN CTR. FOR JUST. (Oct. 2018), https://www.brennancenter.org/ sites/default/files/publications/2018_10_DomesticTerrorism_V2\%20\%281\%29.pdf [https://perma.cc /7XKE-6Z3W].

5. Nichols v. Alley, 71 F.3d 347, 349-50 (10th Cir. 1995). 
blast. ${ }^{6}$ Six hundred and eighty people were injured in the blast. ${ }^{7}$ Many of the dead and injured were children. ${ }^{8}$ America was shocked at the thought that two Americans could kill and wound their fellow citizens.

Both Nichols and McVeigh held strong anti-government beliefs and, during their interrogations after the bombing, both cited the incidents at Ruby Ridge and at Waco as strong sources for their anger. ${ }^{9}$ The incident at Ruby Ridge occurred in 1992 when Randy Weaver, his family, and friends were besieged by federal law enforcement personnel for eleven days. ${ }^{10}$ During the siege, Weaver's wife, son, and dog were killed as was a U.S. Marshal. ${ }^{11}$ The incident at Ruby Ridge thereafter became a rallying call for anti-government groups throughout the United States.

The incident at Waco involved a fifty-one-day siege by federal law enforcement personnel of a group known as Branch Davidians, led by Randy Koresh at the Mount Carmel Center outside of Waco, Texas in 1993. ${ }^{12}$ On the fifty-first day of the siege, U.S. forces launched an attack on the compound, a fire broke out, and seventy-five people-including David Koresh - died. ${ }^{13}$ The events at Waco simply added fuel to the fire already begun by Ruby Ridge and energized anti-government groups throughout the United States. Indeed, Timothy McVeigh visited the site of the Waco tragedy in March 1993 and later attributed his idea to strike at the U.S. government to this visit. ${ }^{14}$ But how did this lead to my involvement with domestic terrorism? It is because Terry Nichols's home was Herrington, Kansas and because after the bombing it was discovered that Nichols had obtained materials that he used in the Oklahoma City bombing in Herrington and McPherson, Kansas.

Nichols's connections with Kansas, in and of themselves, were hardly

\footnotetext{
6. Id.

7. Sejal H. Patel, Sorry, That's Classified: Post-9/11 Surveillance Powers, the Sixth Amendment, and Niebuhrian Ethics, 23 B.U. PUB. INT. L.J. 287, 299 n.56 (2014).

8. Victims of the Murrah Building Bombing, CBS NEws (Apr. 14, 2000), https://www.cbsnews.com/news/victims-of-the-murrah-building-bombing/ [https://perma.cc/2YLJ46B3].

9. Dara Lind, Waco and Ruby Ridge: the 1990s Standoffs Haunting the Oregon Takeover, Explained, Vox (Jan. 5, 2016), https://www.vox.com/2016/1/5/10714746/waco-ruby-ridge-oregon [https://perma.cc/ZVD9-4VNS].

10. Randy E. Barnett, Foreword: Guns, Militias, and Oklahoma City, 62 TENN. L. REv. 443, 454 (1995).

11. Id.

12. Id. at $455-56$.

13. Id. at 456 .

14. Jesse Greenspan, Waco, 20 Years Later: Where Are They Now?, History (Feb. 28, 2013), https://www.history.com/news/waco-20-years-later-where-are-they-now [https://perma.cc/57BTHGZ2] (noting that McVeigh reportedly told his father following his conviction that "[i]t was a bunch of stuff the government did, and the last straw was Waco").
} 
enough to lead to my "connection" with domestic terrorism. However, there were rumors at the time that Nichols had been involved with the militia movement in Western Kansas. There has been a long history of militias in the United States. Originally, every state had a militia. ${ }^{15}$ These were progenitors of modern National Guard units and were an important component of our national military. ${ }^{16}$ The modern militia movement, however, is quite different. Modern militias are private groups organized in quasi-military format. ${ }^{17}$ Some are quite innocent and law-abiding. Others, however, consist of members who hold anti-government views, and some are connected to various white nationalist movements. ${ }^{18}$ Often these groups engage in combat training. Many of the more extreme militia groups believe that the current federal government is illegal and illegitimate and see themselves as protectors of the "true" Constitution as it was intended by the Founders. ${ }^{19}$ Indeed, one of the most popular symbols of the modern militia movement is the Gadsden flag, designed by Revolutionary War General Christopher Gadsden, which carries the motto "Don't Tread on Me," and became a potent symbol of American resistance to British tyranny. ${ }^{20}$ McVeigh's statements after he was captured made it clear that he supported many of the ideals of the modern militia movement, even though he was not an actual militia member. In 2017, the Southern Poverty Law Center identified 689 anti-government groups in the United States, of which 273 were militias. ${ }^{21}$ The Miami Herald estimated that there were 165 armed anti-government militias in 2016 and 276 armed militias in 2015. ${ }^{22}$ In other words, there are tens of thousands of armed, anti-government militia members in the United States. Some live in Kansas. Once again, it is important to note that membership in a militia is not illegal, nor is being armed or holding anti-government views. These are all activities that are constitutionally protected. However, militias frighten many Americans - especially government officials - who see them as "domestic terrorists." And that is how I came to have an

15. Chuck Dougherty, The Minutemen, the National Guard and the Private Militia Movement: Will the Real Militia Please Stand Up?, 28 J. MARshall L. Rev. 959, 964-68 (1995).

16. Id. at 969 .

17. Daryl Johnson, Hate in God's Name, S. PoverTy L. CTR. (Sept. 25, 2017), https://www.splcenter.org/20170925/hate-god\%E2\%80\%99s-name [https://perma.cc/H455-NBEZ].

18. Id.

19. Id.

20. Id.

21. Antigovernment Movement, S. POVERTY L. CTR., https://www.splcenter.org/fightinghate/extremist-files/ideology/antigovernment [https://perma.cc/6Z3Z-9TGQ] (last visited Mar. 24, 2019).

22. Teresa Welsh, Domestic Militia Groups Plummet 40 Percent Amid Trump Rise, MiamI HERALD (Feb. 15, 2017, 4:57 PM), https://www.miamiherald.com/news/nation-world/national/article 132948254.html [https://perma.cc/4XZW-FFEP]. 
involvement with the militia movement.

In 1995 the University of Kansas welcomed a new Chancellor, Robert Hemenway. As all new senior university officers must, Chancellor Hemenway spent much of his first year meeting Kansas officials. At one dinner he spent some time talking to the newly-elected governor Bill Graves. Governor Graves mentioned that a group of militia members from Western Kansas had been coming regularly to the Washburn University Law Library and studying various volumes of the United States Code housed there. According to the Governor, this was making some folks at Washburn rather nervous and was also troubling to the Governor and his advisors. In the aftermath of the Oklahoma City bombing and with knowledge of Terry Nichols's Kansas connections, people were wondering what these folks were up to at Washburn's law library. The Governor also made it clear that the visiting militia members were perfectly respectable and respectful and had done nothing but exercise their right to use the library. Chancellor Hemenway, for reasons that I will never divine, immediately offered to send his Law Dean-me-to meet with representatives of the militia in Western Kansas in the hope of discovering what was going on and whether there was any potential danger to the people of Kansas. ${ }^{23}$

When the Chancellor called me the next day to tell me that he had volunteered my services to Governor Graves as an unofficial emissary to militia members in Western Kansas, I was, to say the least, somewhat perturbed. Indeed, I believe that my first response was to say: "Chancellor, are you out of your mind?" followed by "Sir, do you really think that a Jewish lawyer from New York is the best choice for this duty?" Apparently, he did because I soon found myself making arrangements with members of the Governor's staff to attend a meeting with selected militia members in Western Kansas. I decided that I did not want to go alone so I asked a new member of the faculty, a native Kansan and constitutional law scholar, Steve McAllister, to accompany me, which he bravely did. ${ }^{24}$ Together we drove several hours west from Lawrence on the appointed day and stopped at the courthouse in the Western Kansas town in which our meeting was scheduled. We proceeded to a room in the basement of the otherwise empty courthouse and were greeted very warmly by three people.

23. As it turns out, Kansas is not the only state in which law libraries have had to deal with "constitutionalist" patrons. See Vicenc Feliu, Meeting the Needs of Constitutionalist Patrons: A Guide for Reference Librarians, 25 LEGAL REFERENCE SERVS. Q. 89 (2006).

24. Steve, of course, has gone on to great distinction and serves as the E.S. \& Tom W. Hampton Distinguished Professor of Law at the University of Kansas and the United States Attorney for the District of Kansas. 
We spent approximately three hours with the militia members in the courthouse meeting room. They were intelligent and friendly, and explained to us that their group believed that the federal government, as it was then constituted, was unconstitutional and illegitimate. The militia members thought the government was plotting to harm the members of militia groups in Kansas and around the United States because these groups of patriots were attempting to convince the American people that our government was illegitimate and corrupt. They explained that they were going through the United States Code so that they could identify every unconstitutional law contained therein. We spent quite a bit of time discussing what they had discovered. Chief among their discoveries was that the bank moratorium established by Franklin D. Roosevelt in response to the Great Depression was unconstitutional and still in force since they could not find a statute explicitly repealing it. They also believed that the abandonment of the gold standard by the United States was unconstitutional. They raised quite a few questions about the constitutionality of the Federal Reserve. In addition, they told us that the federal government was using military forces to harass and threaten militia members and that they waited each night for Black Hawk helicopters to appear above their homes and begin firing. Not surprisingly, both Waco and Ruby Ridge featured prominently in the discussion.

There was no mention of armed rebellion by these folks, nor did they threaten any kind of violence against federal or state government. In fact, much to my surprise, these people were determined to study the federal code and use its contents as the basis for proving that the current government was unconstitutional and, therefore, all of its acts were invalid. ${ }^{25}$ It was very clear that the militia members to whom we spoke were highly legalistic and were determined to use the law against the federal government. Perhaps there were darker currents flowing through this group, but in their discussions with us they talked law not weapons.

After my meeting with the militia folks in Western Kansas I became quite curious about the legalism I saw displayed during the meeting and began to do research into the militia and anti-government movements. It was then that I began to do some research into the "Common Law courts" movement. In the wake of the Oklahoma City a number of legal scholars,

25. Interestingly, a version of this argument was made by Secretary of State Michael Pompeo in relation to the Maduro government in Venezuela on January 24, 2019. See Press Release, U.S. Dep't of State, Remarks at the Organization of American States (Jan. 24, 2019), https://www.state.gov/secretary/remarks/2019/01/288560.htm [https://perma.cc/D7LU-YFFV]. According to Secretary Pompeo, the election which put Nicolas Maduro in office was illegal and, therefore, all acts of his government are "illegitimate and invalid." Id. 
particularly those in states with strong militia movements began to write about these "Common Law courts." Among the various articles on the subject, I think that the best is that published by Daniel Lessard Levin and Michael W. Mitchell in the South Dakota Law Review in 1995. ${ }^{26}$

Levin and Mitchell trace the origins and philosophy of the Common Law court movement to the participants' failure to prevail on their claims in legitimate courts and their unwillingness to accept the legitimacy of state federal courts as a result:

Various predecessors of the common-law court movement have been active for over fifteen years; however, there has recently been a substantial increase in the number of cases reaching the courts as a result of common-law court activities which present novel constitutional claims. Many of these cases have arisen out of activists' claims that they are exempt from taxes because they do not live within an area under the jurisdiction of the United States government, that taxes are part of a voluntary contract from which they may excuse themselves, or that the change from the gold standard in 1933 means that the courts no longer have the proper jurisdiction to enforce tax cases. Other cases have concerned diverse types of legal conflicts as activists challenge everything from speeding tickets to D.U.I. convictions to custody disputes. $^{27}$

And:

Common-law court activists have also used the legitimate courts to challenge the legitimacy of the government as a whole and the courts specifically. One favorite claim is that federal and state courts operate improperly as admiralty courts whenever they display a flag with gold fringe. Activists with a conspiratorial bent have accused judicial officers of being "Foreign Double Agents with full intent to overthrow our Constitutional Freely Associated Compact States of our Constitutional Republic" and held a federal judge in contempt of court on their authority as individual sovereigns. Other activists have rejected the government's authority over them because they have a special status as "natural individuals" or "Free Citizens of the Republic of Minnesota" that exempts them from the obligations of United States citizens. In response, the judiciary has increasingly sanctioned those who file such frivolous suits. $^{28}$

Interestingly, Levin and Mitchell see these courts, and the movements behind them, as examples of "American nationalism" and social

26. Daniel Lessard Levin \& Michael W. Mitchell, A Law Unto Themselves: the Ideology of the Common Law Court Movement, 44 S.D. L. REV. 9 (1999).

27. Id. at $10-11$.

28. Id. at 11 . 
"fundamentalism," terms that continue to be controversial today. ${ }^{29}$ While one may debate the historical, social, and philosophical aspects of the Common Law courts, they are fascinating as an indicator of the importance of maintaining a legal or "pseudo-legal" justification of the militia movement's rejection of mainline legal theory and institutions while at the same time emphasizing the importance of a legal framework to legitimate their actions. ${ }^{30}$

Vicenc Feliu, who was the Foreign, Comparative Law, and International Law Librarian at the Paul M. Hebert Law Center Library at Louisiana State University in 2006, wrote of his thoughts on serving patrons he classified as "constitutionalists,"-those who denied the legitimacy of mainstream courts and government-including Common Law court supporters. He described these patrons as:

[T] he typical Constitutionalist patrons I became acquainted with during my stay at the Gallagher Law Library reference desk was a WASP male, "somewhere on the border between middle and old age." My experiences at the Gallagher Law Library with Constitutionalist patrons also showed that the majority tended to be self-educated, self-taught in the law, and working pro se. As a result of their focus on legal self reliance, the Constitutionalist patron is a phenomenon more often encountered in public access libraries. Institutions that restrict access to students or members are less likely to be used by these patrons since they avoid membership in the mainstream legal world. ${ }^{31}$

His comments on patrons who identified themselves as involved in the Common Law courts movement are also quite enlightening:

Constitutionalist patrons can also come from members of the CommonLaw Courts movement. Common-Law Courts are courts organized at the local level outside the recognized judicial system that purportedly apply principles of common law to resolve disputes and adjudicate criminal matters. These courts are based on those developed by the Posse Comitatus Movement, and like them, they meet in private homes or community places. Some of these courts act as instruments of harassment to public officials and the established legal system; others appear to be sincere attempts to implement the beliefs of their members by freeing themselves from what they perceive as state tyranny and holding public officials accountable. Common-Law Courts have been active in their efforts to intimidate public officials and judges by issuing indictments, subpoenas, and by placing common-law liens on the property of those

29. Id.

30. Francis X. Sullivan, The "Usurping Octopus of Jurisdictional/Authority": The Legal Theories of the Sovereign Citizen Movement, 1999 WIS. L. REV. 785, 823 (1999).

31. Feliu, supra note 23, at 91-92 (quoting Mary Whisner, Dictionaries Make Strange Bedfellows, Language and the Law: ProceEdings of a Conference 93, 93 (Marlyn Robinson ed., 2003)). 
failing to comply with their demands. Adherents of these beliefs propose that the authority of their Common-Law Courts is based on the Constitution, as interpreted by them, because they claim to be the highest sovereign power they designate their Common-Law Courts as the "One Supreme Court."

Constitutionalist patrons present a special challenge for the reference librarian because those patrons seek to interpret existing law using sources and materials that are not current or up to date. In addition to favoring antiquated materials, these patrons also seek to support their legal arguments through convoluted connections to arcane law or through unrelated materials based on their interpretation of their favored old re-sources. The reference librarian, trained in the law and generally working with patrons who are either also trained in the law or working to resolve problems using existing law, has to change his or her working paradigm radically to meet the information needs of a Constitutionalist patron effectively. ${ }^{32}$

It would be relatively easy to dismiss the adherents of the Common Law court movement as harmless eccentrics - especially if there is little or no evidence that they are violent. ${ }^{33}$ In effect, those who are involved with the movement might be characterized simply as using alternative dispute resolution methods in lieu of the courts, activities that we now accept as quite legitimate. The problem was and continues to be that the Common Law courts are not simply used to adjudicate disputes among those who use them. ${ }^{34}$ Instead, the Common Law courts have been used to harass and intimidate judges and legislators. ${ }^{35}$ The means of this intimidation have been Common Law court processes brought against judicial and governmental officials, the results of which are the issuance by the court of judgments against the officials. ${ }^{36}$ Often these are financial judgments that find the officials financially liable to those who brought the cases. Indeed, these judgments are then translated into official looking documents, which supposedly may be used against the defendants' property. ${ }^{37}$ Stories of such judgments and lien documents targeted at judicial and governmental officials in states in which there are Common Law courts are legion. In the aftermath of my visit with the militia members in 1995, I often heard such stories when I inquired about these courts.

32. Id. at 94-95.

33. Susan P. Koniak, The Chosen People in Our Wilderness - Gathering Storm: America's Militia Threat by Morris Dees with James Corcoran, 95 MicH. L. REV. 1761, 1761, 1798 (1997).

34. Id. at 94 .

35. Levin \& Mitchell, supra note 26 , at 33.

36. Id.

37. Id. 
Again, such proceedings, court decisions, and documents would, in a perfect world, have no real effect. Unfortunately, many legitimate government officials, such as county records officials and even sheriffs have mistaken these documents for the real thing. In Minnesota, the problem became so severe, that in 1996, the Attorney General issued a formal letter that a sheriff is not "authorized to 'serve' documents that purport on their face to give notice of proceedings in 'courts' that are not established by law ...." ${ }^{38}$ The problem became so serious that by 1998 twenty-seven states enacted laws prohibiting Common Law courts or the issuance of false legal documents. ${ }^{39}$

My third encounter with "domestic terrorism" came when I was researching a biography that I had been asked to write for the Federal District Court for the District of Kansas. It has become a tradition at the Court that when a judge retires a short biography of the judge is commissioned. I was fortunate enough to be asked to write the biography of Judge Kathryn Vratil, the first woman to serve on the District Court and to serve as Chief Judge of the Court. Judge Vratil was a pioneer in many ways and her life has been filled with both excitement and great achievements. But I discovered that a federal judge's life is not quite so quiet or safe as I had once imagined. While going through the Judge's papers, I discovered that she had been the target of threats by a domestic terrorist.

Judge Vratil was not the first Kansas federal judge to be the target of terrorism. On August 5, 1993, Jack Gary McKnight was to appear in federal court in Topeka for sentencing on drug and firearms charges. ${ }^{40}$ McKnight did not appear at the court. ${ }^{41}$ Instead, he went on a violent rampage, exploding a truck bomb in Oskaloosa and then invading the Topeka courthouse firing shots in the hallways and chambers and attempting to explode a pipe bomb. ${ }^{42}$ He killed or wounded five people before he killed himself. ${ }^{43}$

38. Sheriffs: Service of Process, Minn. Op. Atty. Gen. 390a-21 (Nov. 5, 1996), http://www.ag.state.mn.us/office/Opinions/390a21-19961105.pdf [https://perma.cc/JHX9-BC85].

39. 27 States Act Against Antigovernment Movement's Common Law Courts, INTELLIGENCE RPT., June 15, 1998, https://www.splcenter.org/fighting-hate/intelligence-report/1998/27-states-actagainst-antigovernment-movement's-common-law-courts [https://perma.cc/FXS3-PDLF].

40. On this incident see M.H. Hoeflich et al., A Pioneer Judge. Judge Kathryn Vratil (forthcoming 2020). See also, Tim Hrenchir, 25 Years Ago This Week: History Guy recalls attack on Topeka's Carlson Federal Building, TOPEKA CAP. J., (Aug. 1, 2018, 10:49 PM), https://www.cjonline.com/news/20180801/25-years-ago-this-week-history-guy-recalls-attack-ontopekas-carlson-federal-building [https://perma.cc/VTR6-M35U].

41. Hrenchir, supra note 40.

42. $I d$.

43. Id. 
Twenty-two years after McKnight's attack on the federal court in Topeka, Judge Vratil received a letter on August 1, 2005 from Robert S. Milton, then serving a sentence in a federal prison in California. ${ }^{44}$ The letter threatened Judge Vratil with death: "I'm only writing you this letter so you'll know whom is having you and your family executed for crimes against humanity." 45 It is notable not only that the letter threatened to kill both Judge Vratil and her family but also that it was couched in legalistic terms ("crimes against humanity"). ${ }^{46}$ Here, again, we see the propensity of domestic terrorists to justify their actions on allegedly legal bases.

Although Milton, happily, did not act on his threats, they had to be taken quite seriously. In February 2005, the husband and the mother of federal Judge Joan Lefkow, a District Court Judge in Chicago, were brutally murdered. ${ }^{47}$

Judge Lefkow, in the years before the murders, had been provided with twenty-four-hour security by U.S. Marshals because of fear that Matthew Hale, a white supremacist over whose trial she had presided, would take action against her. ${ }^{48}$ Although the murder of Judge Lefkow's family members was a first, federal judges had been killed before. At least one of those murders - that of Judge Robert Vance in 1988 - may have been linked to extremists. ${ }^{49}$ Thus, Milton's threatening letter to Judge

44. See Memorandum of Matters Discussed and Action Taken at Pretrial Conference 1, United States v. Milton, No. 05-20089-01 DW, 2006 U.S. Dist. LEXIS 31097 (D. Kan. May 9, 2006) (noting that Mr. Milton was charged with "mailing threatening communications").

45. The letter and accompanying documents may be found in Judge Vratil's official papers now at the Kansas State Historical Society in Topeka. These papers may be viewed only with permission. See also California State Inmate Gets 10 Years for Threatening Federal Judge, 13 WIBW (Nov. 22, 2006, 9:58 AM), https://www.wibw.com/home/headlines/4719616.html [http://perma.cc/VF2BMHCG].

46. Id.

47. Amanda Paulson \& Brad Knickerbocker, Chicago Murders Spotlight Risks to Judges, THE CHRISTIAN SCIENCE MONITOR (Mar. 3, 2005), https://www.csmonitor.com/2005/0303/p03s01usju.html [http://perma.cc/QM9W-G9CE]. See also Jodi Wilgoren, Electrician Says in Suicide Note That He Killed Judge's Family, N.Y. Times (Mar. 11, 2005), https://www.nytimes.com /2005/03/11/us/electrician-says-in-suicide-note-that-he-killed-judges-family.html [http:/perma.cc/ H2RT-9XKC].

48. Paulson \& Knickerbocker, supra note 47. Ultimately, Bart Ross-a cancer patient whose malpractice case was dismissed by Judge Lefkow - confessed to the murders in a note. Wilgoren, supra note 47. Ross had no known connections with white supremacy groups. Id. Interestingly, Matthew Hale was also the center of important litigation on the interaction of the power of State character and fitness committees' ability to exclude applicants from admission to the Bar and the First Amendment. Hale v. Comm. on Character \& Fitness for Ill., 335 F.3d 678 (7th Cir. 2003).

49. Associated Press, Letter Bomb Kills U.S. Appeals Judge, N.Y. Times (Dec. 17, 1989), https://www.nytimes.com/1989/12/17/us/letter-bomb-kills-us-appeals-judge.html [https://perma.cc /U65G-DG4M]. His murderer, Walter Leroy Moody, was executed on April 19, 2018. Moody had also sent a bomb letter to the NAACP Regional Office in Atlanta and its Jacksonville branch. See Kent Faulk, 'Why my dad?' Judge Recalls Father's Legacy as Bomber's Execution Nears, AL.Com 
Vratil could not be dismissed, particularly since its threat against her family echoed the killing of Judge Lefkow's family mere months before.

Although the incidents and literature I have cited in this essay occurred, for the most part, two decades ago, I believe that they are important to us today. Why? My answer is simple. There seems little doubt that the United States is currently seriously divided along political, social, and racial lines, perhaps more so than ever before in the modern era. ${ }^{50}$ We see increasing militancy on the part of "white nationalists" as evidenced by the violence at Charlottesville and other protests during the past two years. ${ }^{51}$ The rhetoric of white nationalism, espoused even by government officials such as Iowa Congressman Steve King, ${ }^{52}$ has increasingly become public and more strident. To put it plainly, many of the activities described in this essay continue today and pose a serious threat to public security. The fact that so much of our legislative and legal focus since $9 / 11$ has been on the threat of international terrorism has distracted from what I believe to be the very real potential threat from domestic terrorism that may face us today.

We in the United States have tended to be reactive rather than proactive in the face of internal and external threats. One need only look at all of the warning signs that preceded 9/11 to realize that we, as a nation, tend to react to threats only after a tragedy has occurred. In recent years both the federal and state government have done much to counter external terrorist threats, but done far less on the domestic front. Of course, constitutional limitations make domestic legislation far more difficult. But I am becoming far more alarmed that we are simply in a waiting period prior to another incident like the Oklahoma City bombing. I fear, as well, that the public and legislative reaction to increased anti-terrorism activities focused on international terrorism, will impede the ability of law

(Apr. 18, 2018), https://www.al.com/news/birmingham/2018/04/circuit_judge_bob_vance_talks.html [https://perma.cc/DJH4-LRGJ].

50. See, e.g., Livia Gershon, Just How Divided Are Americans Since Trump's Election?, HISTORY (Nov. 8, 2017), https:/www.history.com/news/just-how-divided-are-americans-sincetrumps-election [https://perma.cc/VA77-GCS6].

51. See generally, Dara Lind, Unite the Right, the violent white supremacist rally in Charlottesville, explained, Vox (Aug. 14, 2017), https://www.vox.com/2017/8/12/16138246/ charlottesville-nazi-rally-right-uva [https://perma.cc/G7QP-RQFB]; Emily Moon, How has White Nationalism Changed in the Year Since Charlottesville?, PAC. STANDARD (Aug. 10, 2018), https://psmag.com/social-justice/how-has-white-nationalism-changed-in-the-year-sincecharlottesville [https://perma.cc/C5SR-ALUQ].

52. See Jacob Kurtz, Republicans, Including Iowa Senators, Pile on Condemnation for Steve King's 'White Supremacist' Remarks, DES MoINES REG. (Jan. 12, 2019), https://www.desmoinesregister.com/story/news/politics/2019/01/12/steve-king-iowa-4th-districtwhite-nationalism-supremacy-chuck-grassley-joni-ernst-western-racism/2558823002/ [https://perma .cc/XTD9-U2J2]. 
enforcement to counter domestic terrorism. ${ }^{53}$

Finally, I think that it is extremely important for the legal profession to recognize that the inclination of the radical right in the United States to justify their actions by reference to "pseudo-legal" doctrine puts a particular burden on lawyers to counter these spurious arguments both in public and in private. The general public does not know or understand the complexities of legislative and legal doctrine. Many of the arguments and the rhetoric used by domestic terrorists like Robert Milton or by Common Law courts seem, on the surface, to make sense. Especially in a world in which the idea of "alternate facts" has become acceptable in some circles, it is important for lawyers and judges to educate the public on what the law actually says and means to counter the pseudo-law that is espoused by those who oppose legitimate government. In sum, this essay reflects a growing concern on my part at our unwillingness to confront the dangers that face us today on the domestic front.

53. I am particularly concerned with the "push back" against efforts by law enforcement to track the movements and activities of "bad actors." In particular, I am concerned with the implications of such cases as Carpenter v. United States, 138 S. Ct. 2206 (2018), which, in my opinion, severely limits the ability of law enforcement to track terrorists in the United States. 